\title{
Representation of Political Ideology in Advertising: Semiotics Analysis in Indonesia Television
}

\author{
Rizki Briandana
}

Faculty of Communication Sciene, Universitas Mercu Buana, Jakarta-Indonesia

\begin{abstract}
This study aims to analyze the meaning and symbols in the political party's advertising on Indonesian television. Towards the presidential election, political parties use advertising as a means of marketing communication. As the form of persuasive information, the Perindo Party's television advertisement was analyzed by using Charles Sanders Pierce's Triangle of Meaning for the semiotic method. According to Pierce, the signs in the picture can be classified into the types of signs in semiotics. Pierce divides the signs into: icons, indixes and symbols. The research results show that Perindo Party's Nationalist ideology upholds pluralism in Indonesia. It has special message that Indonesia does not belong to a particular religious, cultural or racial group. The meaning of contemporary nationalism in this advertisement is tried to raise particularly for young people with the aim of developing potential for a better life.
\end{abstract}

Keywords-advertisement, semiotics, political ideology.

\section{INTRODUCTION}

The year 2019 is a political year for Indonesian society who will elect president, vice president and parliamentarians. Through the political parties, it can provide opportunities or hopes for Indonesian citizens to be able to participate or contribute in building the Indonesian nation (Baswedan, 2004). We also know that political parties are the representations of ideas or the reflection of ideals of a country and society (Johnson Tan, 2012). It means that in the present context political parties are media or means of citizen participation in fighting for the ideals of the state and society. Their struggle can be through the process of making and implementing public policies (Mietzner, 2013). The political parties also determine who can be responsible for becoming state administrators working in public institutions at all levels of government from central government to regional ones (Tanuwidjaja, 2010).

Through political parties it can also be a means of national integration (Ufen, 2008). In the political party membership it is open to all citizens, and therefore, their members can come from various provinces, customs, backgrounds and beliefs (Ufen, 2008). Therefore the ideology, vision and mission of political parties should be formed according to the dream or aspiration of the Indonesian State and its people. In other words, it can be main motivation and drive for the activities of political parties (Sen \& Hill, 2006). Political parties are media or means of citizen participation in fighting for the ideals of the state and society (Gazali, Hidayat, \& Menayang, 2009). For this reason, it is indisputable that political parties will be developing. On the other hand, for political actors it is an opportunity to establish a new party (Baswedan, 2004). With the emergence of new parties, the election process in Indonesia has resulted in sharp competition between political parties. When a political party's main task increases, it will focus on taking people's hearts with "frills" or the reason that "all this time the political parties care about people's problems" (Tanuwidjaja, 2010).

In order to create a conducive political atmosphere and make the people of Indonesia disappointed, the process of selecting the political parties to be able to take part in the general election will be increasingly tightened (Ufen, 2008). The selection has been regulated in the Laws and Regulations of the Republic of Indonesia, i.e. Law Number 8 Year 2012 concerning General Elections of The Members of the House of Representatives, People's Representative Council and Regional House of Representatives (or it is usually called as Election Law).

According the laws and regulations having been made, it does not reduce the motivation of the political parties to struggle particularly picking up people's heart as many as possible (Honna, 2013). Particularly if a new political party has the main task of introducing its party, people can get to know, know and "who knows" they want to participate as members of the new political party (Gazali et al., 2009). Therefore, the founders and party administrators are required to be smart in making strategies, one of which is a strategy to increase public awareness, i.e. through advertisements (Holtz-Bacha \& 
Kaid, 2014). The installation of political advertisements in the mass media is one easy way to introduce the new political party to public (Morissan, 2016).

Advertising is one of the promotional media that can be used as a tool for sending messages (Kotler, Kartajaya, \& Setiawan, 2016). It aims to shape and change consumer or societal behavior. One function of advertising is social function. The advertising brings influences in such a manner on emerging new cultures such as creating consumerism, new social status, pop culture and others (Kaid \& Holtz-Bacha, 2006). It is also one of the media that is able to construct people's minds.

Media content is definitely the result of reality construction with language as its basic device (Bungin, 2008). "The language use (selected words) expresses choice, attitude, tendency of communicators and it is intended to send messages to senders and recipients (Mcmillin, 2016). In advertising, language is used as a means of exchanging messages and it becomes a communication tool between producers and consumers (Elliott \& Wattanasuwan, 1998). Through pictures or photos and words or texts, an advertising produces a sign (Richards \& Caywood, 2014). In the advertising, it contains a signifier and signified (Mcilwain, 2007). Moreover, it forms a denotative meaning with explicit meaning and it only deliver information and a connotative meaning that involves feelings, emotions and cultural values (Solík, 2014). In other words, the signifier is "meaningful sound" or "meaningful streak". All of this forms a communication process and it has important strength as a marketing means in a form of persuasive information (Najafian \& Ketabi, 2011b).

Based on the research background, the researchers will analyze the advertisement of a political partiy in Indonesia, i.e. the PERINDO party version of "Who is Indonesia" in the period 2019 on RCTI television by using semiotics from Charles S. Pierce.

\section{CONCEPTUAL FRAMEWORK OF THE STUDY}

\section{Meaning of Signs in Communication}

In communication there is a process of delivering messages or goals from the giver to the message recipient (Solík, 2014). Moreover, in the process of communication it somestimes use signs or symbols as a means of delivering information (Najafian \& Ketabi, 2011b).

Construction in principle is the process of interpreting or giving meaning to messages (Freire, 2014). Before the messages are delivered, the communicator selects and process the message whether the communicant will easily accept the messages or not. Moreover, the communicant will interpret the messages having been delivered to him/her (Harvey \& Evans, 2001). If the meaning that the communicator intends through the messages is the same as the communicant's intention, communication can be stated successful, i.e. the meaning equation (Sendjaja, Rahardjo, Pradekso, \& Sunarwinadi, 2014).

Signs are throughout human life (Fiske, 2012). If the signs is on human life, the signs can also be in human culture and these become a sign system used as a regulator of their lives (Fiske, 2012).

The messages conveyed to the communicant have signs. Each sign conveyed in the messages has meaning. In the explanation of Umberto Eco, the meaning of a sign (vechile-sign) is a cultural unit that is exhibited by other signatures and therefore, semantically it shows the dependence on the vehicle and the previous sign (Eco, 1986).

Eco (1986) states that we can only think with the medium of sign. Humans can only communicate through means of sign. Noth explains that signs in human life can be signs of motion or gesture (Eco, 1986). A wave of the hand can be interpreted as calling or nodding of the head up and down can be translated as agreement (A. Berger, 2010). Sound signals are among others whistle blows, trumpets, genders, human voices, telephone ringing. The sign of writing includes letters and numbers. It can be a sign of picture in the form of traffic signs and others (Holland, Warwick Blood, \& Thomas, 2015).

The efforts to understand meaning is actually one of the oldest philosophical problems in human age (Morley, 2003). The concept of meaning has attracted the attention of communication science, psychology, sociology, anthropology and linguistics (Morley, 2003). It is why some communication experts often refer to the word meaning when they formulate the definition of communication (Holland et al., 2015).

\section{Construction of Reality in Advertising}

The study of social reality in relation to advertising is not a mirror of honest reality. The mirror tends to distort, exaggerate and select the signs. The signs or images do not reflect reality but these say something about reality (Bungin, 2008).

According to Peter L. Berger and Thomas Luckman, reality construction is a social process through actions and interactions in which individuals are continously creating a reality that is owned and experienced together subjectively (Berger \& Luckmann, 1991).

The reality construction of advertising mostly takes material from daily life. This will defnitely determine that the display of advertisements can be read in the right way (Berger \& Luckmann, 1991). However, 
the taking of reality itself is carried out through a selection process and it will determine which ones to take and which ones to eliminate. Furthermore, the taken reality is integrated into the system of advertising meanings and finally it emerges the reality of advertising (Bungin, 2008).

With the construction of social reality, people are interested in selecting a particular brand despite other brands hit them around the head (Briandana \& Dwityas, 2018). They do not switch to other brands. As a matter of fact, they tend to build loyalty to the brand (brand royalty) (Bianchi, 2011).

Advertising does not claim that what is depicted in advertising is the reality as it is but it is the reality that should be. It tries to equal or exceed the value of life. Advertising presents characters, and it is only as the incarnations of larger social categories (Harvey \& Evans, 2001).

The phenomenon of something that happens in society is the result of advertising construction (Freire, 2014). Like the standard of beauty delivered through advertising, it becomes a benchmark for beauty standards in society. If according to advertisements the standard of beauty in society changes, the special reality construction of beauty will changes as well. In other words, advertising create and direct the standard of public beauty (Najafian \& Ketabi, 2011a).

\section{The Semiotics of Charles S. Pierce}

Pierce says that the sign itself is an example of the first, the object is the second element and the interpreter is the intermediary element that acts as the third (Fiske, 2012). The three exists in the context of creating signs and these evokes infinite semiotics, as long as an interpreter (idea) reads the sign as a sign for another (ie. the representative of a meaning or sign) can be captured by other interpreters (Sobur, 2001). This interpreter is an element that must exist to associate the sign with the object (induction, deduction and capture [hypothesis] form three important types of interpreters). In order to exist as a sign, the sign must be interpreted (and means to have an interpreter) (Sobur, 2001).

For Pierce, the sign "is something which stands for something in some respect or capacity" (Morley, 2003). It means that when something is used to make sign function, Pierce calls it ground. Consequently, sign or representamen is always found in the triadic relations, i.e. ground, object and interpretand. On the basis of this relationship, Pierce makes a classification of the sign. For Pierce, the sign associated with ground becomes qualisign, sinsign and lesign (A. Berger, 2010). Qualisign is the quality that is on the sign, for example harsh, hard, weak, soft and melodious words (A. Berger, 2010). Sinsign is the actual existence of objects or events that are on the sign; for example the word fuzzy or murky which is in the word order of murky river water, it indicates that there is rain in the upstreeam (A. Berger, 2010). Lesign is the norm contained in the sign, for example traffic signs that indicate things that human may or may not do (A. Berger, 2010).

Pierce's theory frequently refers to as a 'grand theory', i.e. a theory that explains all social life, history, or human experience (Sobur, 2001). It is more because Pierce's ideas are comprehensive, structural descriptions of all sign systems. Pierce wants to identify basic particles from the sign and recombine all components in a single structure (Sobur, 2001).

Referring to Pierce's theory, the signs in the picture can be seen from the types of signs classified in semiotics (A. Berger, 1997). Pierce divides signs into some types: icons, indixes and symbols. Pierce considers that this is a very useful and fundamental model of sign characteristics. A sign is something that represents something. Something can be in the form of experience, thoughts, ideas or feelings (A. Berger, 2010). If something, for example $\mathrm{A}$, is black smoke that billows in the distance, it can represent $B$, for example a fire (experience). Such a sign can be referred to as an index which is between A and B there is a contiguity. The sign can also be symbol or symbols. Pigeon is believed as a sign or symbol of peace; the pigeion cannot just be replaced with other birds or animals (A. Berger, 2010).

Icons are the relationship between signs and objects or references that are similarity (showing a resemblance), this is frequently clear in visual signs such as a person's photo can be called an icon; a map is an icon; the picture taped to the door of the men's and women's restroom is an icon. Basically an icon is a sign that can describe the main characteristics of something despite something that is commonly referred to as a reference object is not present. An icon is a physical object (two or three dimensions) that resembles what it presents (Eco, 1986). An index is a sign that has a causal relationship with what it represents. Or a sign is called as proof. For example: smoke and fire, smoke will indicate the presence of fire around it (Eco, 1986). The footprint on the ground is an index sign of people passing through the place. A signature is an index of the presence of someone who has incised the signature. Symbols are signs on the basis of conventions, regulations or agreements that are mutually agreed upon. New symbols can be understood if someone already understands the meaning agreed upon. A new symbol can be understood if someone already understands the meaning that has been 
agreed before. The relationship between icons, indices and symbols is confessional (Eco, 1986).

The relationship between the symbol, thought of reference (mind or reference) and referent (reference) can be illustrated through the following semiotic triangle:

\section{Representamen (Sign)}

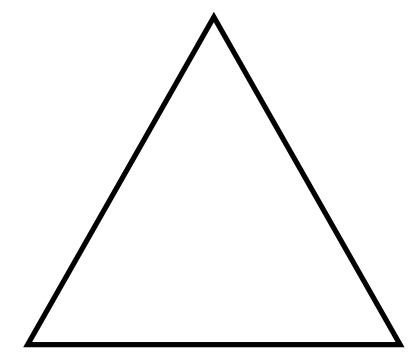

Interpretant

\section{Object}

Fig.1: Triangle

Source : Alex Sobur (2001:159)

Based on the picture at above, it can be explained that mind is the mediation between symbol and reference (Sobur, 2001). On the basis of the thought results it also produces reference, i.e. results of the depiction and conceptualization of symbolic reference. Therefore, the reference is a description of the relationship between linguistic signs in a kind of words and sentences with a reference that produces a certain understanding (Sobur, 2001). Symbols are different from signs. The symbols have a deeper meaning. These are a sign on the basis of conventions, regulations or agreements that are mutually agreed upon (Sobur, 2001). A new symbol can be understood if individuals already understands the meaning that has been agreed previously. Triangle theory from Pierce explains the concepts of sign, object, and interpretant. In the sign stage, the researchers will observe every sign that appears. These will be captured by using the five senses which are object references. Objects are social conditions that occur, and it enters into the interpretant stage (A. Berger, 2010).

\section{METHODOLOGY}

This research uses Charles Sanders Pierce's semiotic methods. The semiotic method is basically a method that focuses on the signs and texts as the research object, and how the researchers interpret and understand the meaning behind the signs and the texts (Creswell \& Miller, 1997). The reason the researchers use the semiotic methods from Charles Sanders Pierce, i.e.: The first reason bases on the purpose of the research. This research aims at providing an overview of the signs that include the meaning of icons, indixes, and symbols of the PERINDO party's advertisement version of Who is Indonesia on RCTI television media in 2019.

\section{Unit of Analysis}

The unit of analysis in this research is the scene by scene or picture pieces in the PERINDO party's advertisement version of Who is Indonesia on RCTI television in the period of 2019. With the research goal, the researchers want to provide an overview of the signs that cover the meaning of icons, indixes, and symbols on the PERINDO party's advertisement version of Who Indonesia on RCTI television media in the period of 2019. There are 23 scenes.

\section{Data Collection Techniques Primary Data}

The data collection technique used in this research is through observation and analys is of the data of PERINDO Party's advertisements in the version of Who is Indonesia on RCTI television media in the period 2019. Furthermore, the researchers conducted examination to the three objects through observation and analysis to the signs visualized in the advertisement.

\section{Secondary Data}

Secondary data in this research are data that the researchers obtained from the existing literature (books, magazines, internet and literature) and it can support primary data and relate to the research problem that the researchers have discussed (Jankowski \& Jensen, 2002).

Table.1: Identification of signs in the text of PERINDO Party's Advertisement

\begin{tabular}{|l|l|l|}
\hline $\begin{array}{l}\text { Types } \\
\text { of Sign }\end{array}$ & Explanation & Unit of Analysis \\
\hline Icons & $\begin{array}{l}\text { (signs connect to the } \\
\text { objects due to some } \\
\text { similarities })\end{array}$ & $\begin{array}{l}\text { Pictures of figures, } \\
\text { words or sentences, } \\
\text { the clothes they wear }\end{array}$ \\
\hline Indexes & $\begin{array}{l}\text { (Proximity between the } \\
\text { signs and the objects or } \\
\text { the existence of a causal } \\
\text { relationship) }\end{array}$ & $\begin{array}{l}\text { Atmosphere } \\
\text { displayed in the } \\
\text { advertisement, music } \\
\text { instruments, sound } \\
\text { displayed. }\end{array}$ \\
\hline Symbol & $\begin{array}{l}\text { (The types of signs that } \\
\text { a number of people or } \\
\text { society have agreed } \\
\text { upon) }\end{array}$ & $\begin{array}{l}\text { Logo, slogan text, } \\
\text { headline text, body } \\
\text { copy text. }\end{array}$ \\
\hline
\end{tabular}

The signs that have been identified and explained in Table 2 have been adapted from the semiotic triangle of Charles S Pierce as follows: 
Table.2: Analysis of Meaning of Sign Types (Icons, Indexes, Symbols)

\begin{tabular}{|l|l|l|l|}
\hline No & Objects & $\begin{array}{l}\text { Signs (Icons, } \\
\text { Indexes, Symbols }\end{array}$ & Interpretants \\
\hline 1 & (objects that & (signs that & (make \\
& become & have been & meaning of \\
& target to be & identified to & the signs that \\
he icons, & have been \\
& interpreted & indexes and & identified) \\
& by & symbols) & \\
\hline
\end{tabular}

Source: (Sobur, 2001)

\section{FINDINGS AND DISCUSSION}

The identification and classification of signs in this research were carried out by adapting the types of signs between the object's relationship and the sign from Pierce. So, after researching and paying attention the picture parts contained in the PERINDO party's advertisement version of Who is Indonesia? on RCTI television media in the period of 2019. Finally, the researchers identified a sign that would become the analysis unit in this research. It sorted out the picture parts of the PERINDO party version of Who is Indonesia? on RCTI television media in the period 2019 as follows:

\section{Table.3: Analysis of PERINDO Party's Advertisement in} Scene 2

\begin{tabular}{|l|}
\hline Scene 2 \\
\hline \\
Picture Description \\
A woman figure who wears kebaya (Indonesian \\
dress). \\
The audio visual says "Are they born from Javanese \\
women?" \\
Background in the picture is full black. \\
Analysis \\
Icon. It is shown a woman figure wears Indonesian \\
dress (kebaya). Kebaya is a type of dress that \\
Javanese women wear particularly in the cultural \\
environment of Yogyakarta and Surakata, Central \\
Java Province. For a Javanese woman, kebaya is not \\
only a dress but also it has its own philosophy. A \\
philosophy that contains the values of life. The
\end{tabular}

refinement, and the act of the woman who must be very gentle. Its simple form can indicate a form of simplicity from the people of Indonesia. Wearing a kebaya will make the woman graceful and full of personality. It is why Javanese women are always synonymous with graceful personality. And, it is why the first Javanese tribes is mentioned in this advertisement? Javanese tribe is the largest in Indonesia and right now there approximately $95,000,000$ people who live in this country.

\section{Indexes.}

Firstly, the kebaya color is: Green, and the audio visual says "Do Javanese people bear them?".

1) The use of green kebaya in this advertisement, can give the impression of being striking, and green can also make you look more fresh and beautiful.

2) The audio visual says "Do Javanese people bear them?". The spoken sentences are the question sentences. That is, PERINDO or the producer of this advertisement intends to attract the attention of readers or audiences. Usually the individuals are asked, they will give an answer and try to find the answer.

Secondly, the question sentences in the advertisement, "Do Javanese people bear them?" are the rhetorical question style. The question is actually not intact to answer or does not require an answer because it aims to achieve a good effect and a reasonable emphasis on an object. The use of this language question will attract the attention of the audience. Usually individuals are asked they will give an answer and try to find the answer. Therefore, thus the advertiser can attract the attention of the readers or audience.

Symbol. In this matter, it is black background. Black itself has meaning and it gives the impression or symbolizes protection, and strength. The strength here means that it wants to highlight other colors and it make the other colors stand out or have strong impression. Therefore, people's attention will be attracted to the opponent colors of black color itself. 
Table.4: Analysis of PERINDO Party's Advertisement in Scene 3

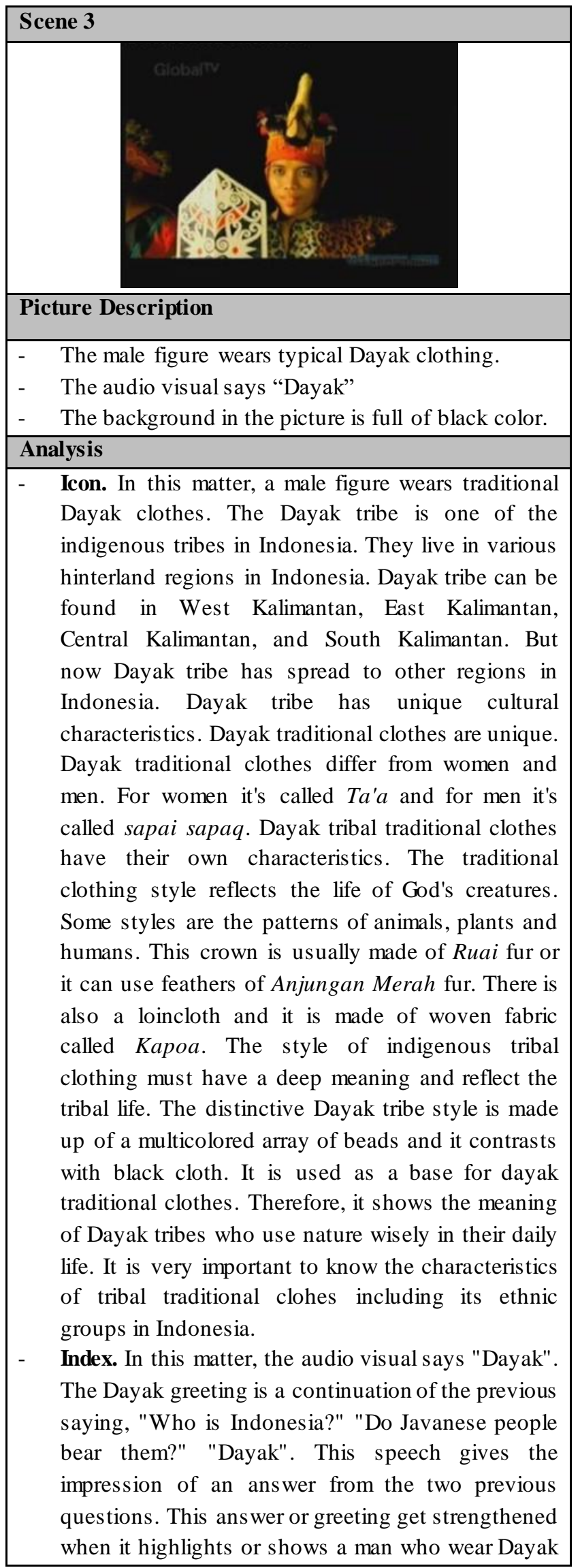

tribal clothes. With this direct answer, it gives the impression that some audiences agree what the advertiser or PERINDO has given.

Simbol. In this matter, background has black color. Black itself has a meaning that it gives the impression or symbolizes protection, and strength. The strength here means that it wants to highlight other colors and it makes them stand out or has a strong impression. Therefore, people's attention will be attracted to the opponent color of black itself.

Table.5: Analysis of PERINDO Party's Advertisement in Scene 4

\begin{tabular}{l} 
Scene 4 \\
\hline \\
Picture Description \\
A male figure wears traditional clothes of Papuan \\
tribe \\
The audio visual says "Papua" \\
The background of the pictgure is full of black \\
color. \\
Analysis \\
Icon. In this matter, the male figure wears \\
traditional clothes of Papuan tribe. Papuan \\
traditional clothing is one of the unique and \\
interesting traditional clothes. If other traditional \\
clothing uses soft clothing materials or similar ones, \\
the traditional clothing of Papua tribe is very \\
different. In accordance with the region where they \\
live, i.e. mountainous areas, their traditional \\
clothing is clothes made from nature around them. \\
Moreover, the Papuan traditional clothing is unique. \\
The subordinate clothing only uses skirts, and \\
therefore, their body parts are not covered. Papuans \\
are very creative they paint their entire bodies so \\
that they are not too clear. They also paint their face \\
from. the paintings. Usually they do not forget to \\
hold spears or arrows and shields in the hand of \\
- \\
- \\
-
\end{tabular}


impression of how grateful they are to nature.

Index. In this matter, the audio visual says "Papua". The phrase "Papua" is a continuation of the previous saying, "Who is Indonesia?" "Do Javanese people bear them?" "Dayak" "Papua". This speech gives the impression of answers from the previous two questions. This answer or greeting get reinforced when the advertisement highlights or displays Papuan male who wears his traditional Papuan clothes. With this direct answer, it gives the impression that some audiences agree with what the advertiser or PERINDO has given.

Symbol. In this matter, the background has black color. Black itself has a significant meaning. It gives the impression or symbolizes the protection, and strength. The strength here means that it wants to highlight other colors and it makes them stand out or has a strong impression. Therefore, people's attention will be attracted to the opponent colors of black itself.

Table.6: Analysis of PERINDO Party's Advertisement in Scene 7

\begin{tabular}{l} 
Scene 7 \\
\hline \\
Picture Description \\
A man figure is a Muslim who wears very well \\
The background in the picture is full of black color \\
The audio visual says "Are they Muslims?" \\
Analysis \\
Icon. In this matter, the figure of Muslim man \\
dresses firmly. The dress is called Koko clothes. It \\
is very synonymous with Muslim fashion. Muslim \\
men in Indonesia commonly wear it. The trend of \\
wearing koko clothes for Muslim men seems to \\
have become a necessity in their daily religious \\
activities when they participate in large religious \\
activities or go to mosque. JJ Rizal also expresses a \\
similar opinion. The history of koko clothes in \\
Indonesia very closely relates to the customs of the \\
Chinese Indonesians when they blend in with the \\
indigenous people. Therefore, it is widely adapted in \\
various tribes in the archipelago. It is believed that \\
the initial design of the koko clothes we know today \\
\hline
\end{tabular}

derives from the habit of Chinese men who use Tui khim clothes. These were common clothes they wore at that time.

Index. Firstly, the sound or audio visual says "Are they Muslims?" The said question sentence has the meaning that PERINDO or the producer of this advertisement intends to attract the attention of readers or audiences. Usually individuals are asked, they will give an answer and try to find the answer. And the mention of Islam as the first answer, fact shows that Muslims in Indonesia are the majority. According to the 2010 census, there are $87.18 \%$ of 237,641,326 Indonesians who were Muslims, 6.96\% were Protestants, $2.9 \%$ were Catholic, $1.69 \%$ were Hindu, $0.72 \%$ were Buddhists, $0.05 \%$ were Kong $\mathrm{Hu} \mathrm{Cu}, 0.13 \%$ of other religions, and $0.38 \%$ were not answered or not asked.

Secondly, the question sentence contained in the advertisement is "Are they Muslims?" It is the style of language rhetorical questions. The question does not get answer totally or it does not require an answer. It aims to achieve a good effect and a reasonable emphasis on the object. The use of this language question will attract the attention of the readers. Usually individuals are asked they will give answer and try to find the answer. Therefore, the advertiser can attract the attention of the readers or audiences.

Symbol. In this matter, the background has black color. Black itself has meaning. It gives the impression or symbolizes the protection, and strength. The strength here means that it wants to highlight other colors and it makes them stand out or has a strong impression. Therefore, people's attention will be attracted to the opponent colors of black itself.

Table.7: Analysis of PERINDO Party's Advertisement in Scene 8

\begin{tabular}{|l|}
\hline Scene 8 \\
\hline
\end{tabular}


- The background from the picture is full of black color

- The sound or audio visual says "Catholic"

Analysis

Icon In this matter, the man figure wears white dress with cross necklace. The cross is a symbol of Catholic belief. The spread of Catholicism began since the arrival of the Portuguese in Indonesia. There were several missionaries when Portuguese arrived in the 16th and 17th centuries in the East, i.e. in Maluku and Flores, NTT. New Catholicism entered Java during the reign of Herman Willem Daendels in early 19th century in Batavia. Daendels established the first church there in 1807 and the Vatican recognized it. In 2010, there were 6,907,873 people $(2.9 \%)$ of Indonesia's total population of 237,641,326 people whose religion were Catholic (Central Statistics Bureau, 2010). White clothes are the symbol of bright colors, candlelight, colors for the role of God's angels, saints and colors for the glorified Christ. The color symbolizes holiness and cleanliness. Therefore, this color is used in the Christ-related feast, for example Christmas, Easter, the Ascension of the Lord Jesus, and a favorite time for example in the ministry of Baptism and Holy Communion.

Index. In this matter, the sound or audio visual says "Catholic" This sentence is a continuation of the previous sentence, i.e. "Who is Indonesia" "Are they Muslim?" "Catholic". This sentence means that PERINDO or the producer of this advertisement, intends that PERINDO wants to attract the attention of the public, and it also wants to inform that there is Catholicism in Indonesia.

Symbol. In this matter, the background has black color. Black itself has meaning that it gives the impression or symbolizes the protection and strength. The strength here means that it wants to highlight other colors and it makes them stand out or has a strong impression. Therefore, people's attention will be attracted to the opponent color of black color itself.
Table.8: Analysis of PERINDO Party's Advertisement in Scene 9

\begin{tabular}{|l|l|}
\hline Scene 9 \\
\hline
\end{tabular}

Picture Description

- The male figure wears black cloth like a toga with white collar and his religion is Catholic

The background in the picture is full of black color.

- The sound or audio visual says "Catholic"

Analysis

- Icon In this matter, The male figure wear black shirt like a toga with white collar. Most Christian churches in Indonesia are familiar with such official clothes. They take over them from their partner churches in the West. The shape is almost the same as a black toga (dress) and it uses "bef" (white tie) with or without a stolla (cloth or wide and long ribbon). A priest is easily recognized when he wears a black or white robe in the worship service. If outside of worship or in the field of service a priest will be easily recognized when he wears priest shirt or collar shirt. In Indonesia when someone wears a collar, the wearer is identified as a priest. The wearer of collar clothes in Indonesia in general is a prostestan priest. These clothes have such meanings: showing the identity of the pastors as well as showing their closeness with God through surrendering themselves to the ordination call they have received. The pastor also shows his obedience to imitate Jesus in material poverty. And it remind a pastor to keep his speech and behavior in order to be appropriate and reflect his identity as a servant who must testify to the Lord Jesus

Index. In this matter, the sound or audio visual says "Protestant". This sentence is a continuation of the previous sentence, i.e. "Who is Indonesia" "Are they Muslim?" "Catholic" "Protestant". This sentence means that PERINDO or the producer of this advertisement intends: Firstly with the existence of the previous question sentence and at the same time it is the answer sentence, such as the word of "Protestant". This gives meaning that some audiences agree with what the advertiser or PERINDO has given. Secondly, PERINDO wants to 
the attention of the public, it also wants to inform them concerning Protestant religion in Indonesia.

Symbol. In this matter, the background has black color. Black color itself has meaning that it gives the impression or symbolizes the protection and strength. The strength here means that it wants to highlight other colors and it make them stand out or has strong impression. Therefore, people's attention will be attracted to the opponent colors of black itself.

Table9: Analysis of PERINDO Party's Advertisement in Scene 10

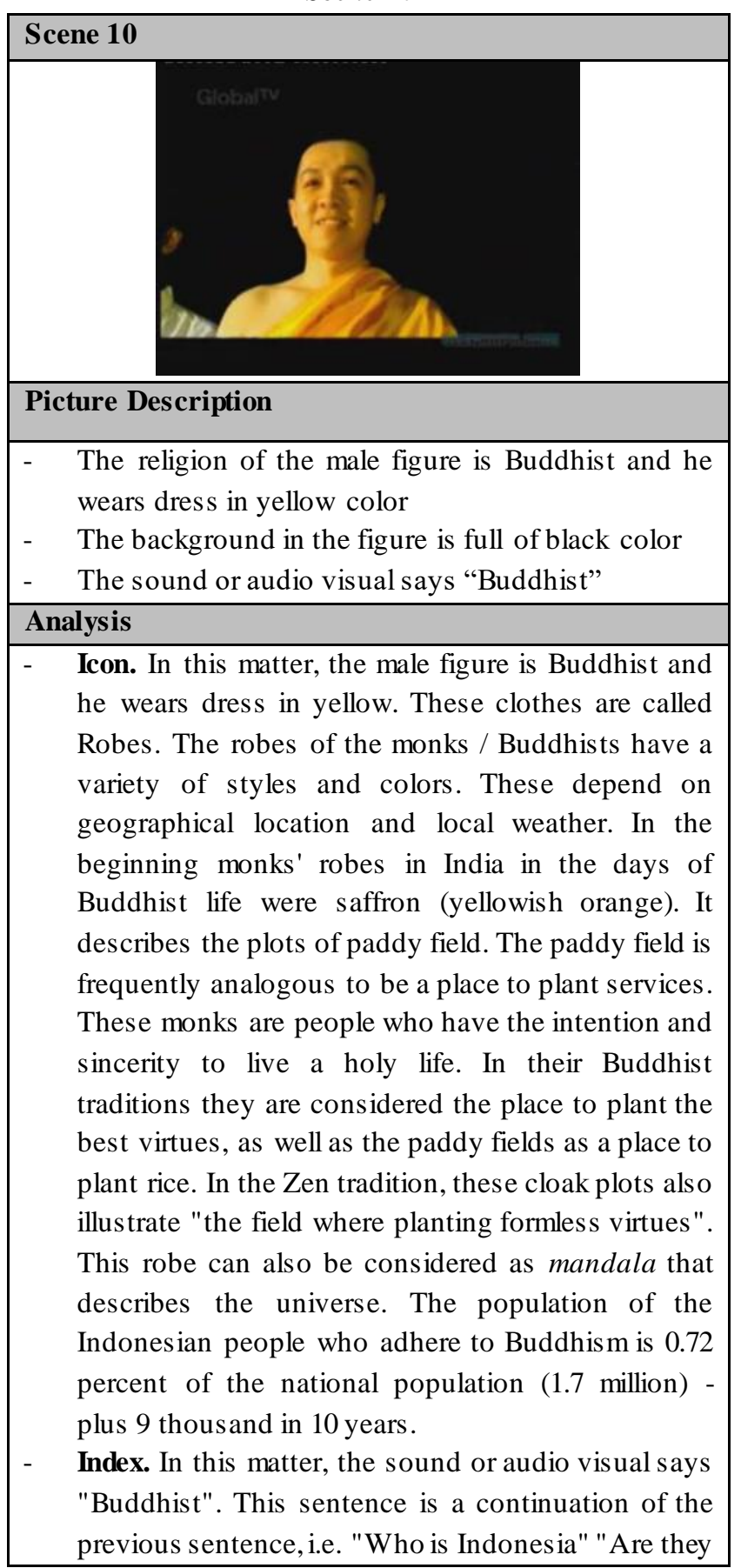

Muslim?" "Catholic" "Protestant" "Buddhist". This sentence means that PERINDO or the producer of this advertisement intends: Firstly with the existence of the previous question sentence is at the same time the answer sentence, such as the word of "Buddhist". This gives meaning that some audiences agree with what the advertiser or PERINDO has given. Secondly, besides wanting to attract the attention of the public, PERINDO also wants to inform that there is Buddhism in Indonesia.

Symbol. In this matter, the background has black color. Black itself has meaning that it gives the impression or symbolizes the protection, and strength. The strength here means that it wants to highlight other colors and it make them stand out or has strong impression. Therefore, people's attention will be attracted to the opponent colors of black itself.

Table.10: Analysis of PERINDO Party's Advertisement in Scene 11

\begin{tabular}{l} 
Scene 11 \\
\hline Picture Description \\
The religion of the male figure is Hindu and he \\
wears yellow shirt with brown headband \\
The background in this picture is full of black color \\
The sound or audio visual says "Hindu" \\
Analysis \\
Icon. In this matter, the religion of the male figure \\
is Hindu and he wears yellow shirt with brown \\
headband. Hindu culture and religion arrived in \\
Indonesia in the first century AD and it coincided \\
with the arrival of Buddhism. Later there were a \\
number of Hindu-Buddhist kingdoms in Indonesia, \\
such as Kutai, Mataram and Majapahit. Prambanan \\
Temple is a Hindu temple built in the Sanjaya \\
kingdom lived until the 16th century AD, when the \\
Islamic empire began to develop. This period, \\
known as the Hindu-Indonesian period and it lasted \\
for 16 centuries. In the records, there were 6.5 \\
- $8 \%$ of Indonesia's population and about $93 \%$ of \\
\hline - Hindus in Indonesia in 2006. It amounts to \\
-
\end{tabular}


Hindus live in Bali. Bali is known with nuances of customs and culture. Definitely it has many philosophies behind the nuances. Bali is also known as the thousand Pura Island. Pura is a holy place for Hindus to worship in Bali. Hindu clothing itself has philosophical meanings. Firstly, the Upper part is the Head (Symbolizing the Gods). For son he should wear udeng on the head and it is frequently called Prabu. It is the place where the Gods reside. These are Intellect, Mind, and the beginning of all actions blessed by Hyang Widhi. And it creates the impression of clear and peaceful mind. The udeng tip or the udeng buds must be straight up. Why? It is the symbol of the wearer establishing the users to think straight, adore the Above. Secondly, it is the middle part of the chest-waist (Symbolizing Man). It means that clothes are worth wearing and comfortable. It can make the users intensively when they are praying. It is recommended that it uses white color again. The bottom three is Waist-Edge (symbolizings Bhuta), Bhuta or giant that occupies the lower realm, the symbol of evil. It will never escape from human beings. Generally Hindus wear Kamen or cloth wrapped from waist to toe. What must be considered is the tie shawl that ties the waist. It must be strong. It is the symbol of Bhuta and it will not be able to enter the human body or to higher one such as to the god.

Index. In this matter, the sound or audio visual says "Hindu" This sentence is a continuation of the previous sentence, i.e. "Who is Indonesia" "Are they Muslim?" "Catholic" "Protestant" "Buddhist" "Hindu". This sentence means that PERINDO or the producer of this advertisement indicates: Firstly, the existence of the previous question sentence is at the same time the answer sentence, such as the word of "Hindu". It gives meaning that some audiences agree with what the advertisement makers or PERINDO. Secondly, besides wanting to attract the attention of the public, PERINDO also wants to inform them that there is Hinduism in Indonesia.

Symbol. In this matter, the background has black color. Black color itself has meaning that it gives the impression or symbolizes the protection, and strength. The strength here means that it wants to highlight other colors and it make them stand out or has a strong impression. Therefore, people's attention will be attracted to the opponent colors of black itself.

Through the analysis results on Perindo's political advertisement version, i.e. "Who is Indonesia" it can be shown how the sign elements in the advertisement build a triadic relationship, and it is appropriate to Pierce's Theory of Signs (A. Berger, 2010). Advertising with creative ideas underlies the storyline of this advertisement and it raise the nation's creative figures who have works and achievements as a form of their love for the homeland (Freire, 2014).

All signs used in this advertisement denote objects and mental concepts and each relates each other (Najafian \& Ketabi, 2011b). Finally, the overall meaning conveyed to the audience can be received as a whole.

The selection of themes, the use of advertising figures, and the soundtrack chosen in the creative execution of Periondo advertisement convey a representation of the meaning of the Political Ideology (Solík, 2014).

Contemporary nationalism meaning in this advertisement is tried to be revived particularly for young people particularly as the use of endorsers (Baines, Crawford, O'Shaughnessy, Worcester, \& Mortimore, 2014). Through their efforts to work and achievement, they develop domestic potential for a better life. Here audience is also aroused with a sense of nationalism they will love domestic products and domestic work amid the onslaught of globalization and the entry of foreign products (Baines et al., 2014).

The audio and visual elements identified in the advertisement are the elements that have strong message. The song is one of the national songs that the general public has known well. Backsound in this advertisement is also clearly played and therefore, audiences can receive messages conveyed through a blend of audio and visualization (Richards \& Caywood, 2014).

In the aspect of visualization, the message from this advertisement enters into the appearance of the advertising figures. When choosing young achievers, it is expected that the society, particularly young people, will not only become the consumers of foreign-made products but also they are invited to recognize and love domestic products. Moreover, it is hoped that the sense of nationalism that wants to be revived from the society can be demonstrated with work through the use of resources and wisdom values that the Indonesian people have possessed all this time.

\section{CONCLUSION}

The conclusion in this research is as follows. Firstly, based on the meaning of the Icon and Indextype, the citizenship meaning has some meanings:

1) Party ideology. In this advertisement Perindo will convey the message that the party's ideology aims to create Indonesia with progressive, united, just, 
prosperous, prosperous, sovereign, dignified and cultural characteristics.

2) Perindo Party makes Pancasila the party's ideology and believes that Pancasila is a true, right, and saving ideology. It has been tested and proved and therefore, it is able to pass various tests and trials of disintegration in the nation's journey safely, and it unites a very diverse nation success fully.

3) Through this advertisement, Perindo wants to convey that this advertisement aims to improve the quality of the Indonesian people who are virtuous, personable, independent, responsible and full of care for others.

Secondly, based on the meaning of the Symbol type, the meaning of citizenship represents the advantages of the Perindo party or the party's positioning as well, i.e.: that as Indonesian citizens we must care for others. The people's problem is not only solved with promises but also these must be proven in a real way. So, Indonesia will be prosperous.

\section{ACKNOWLEDGEMENTS}

I would like to show our gratitude to the research centre at Universitas Mercu Buana.

\section{REFERENCES}

[1] Baines, P., Crawford, I., O'Shaughnessy, N., Worcester, R., \& Mortimore, R. (2014). Positioning in political marketing: How semiotic analysis adds value to traditional survey approaches. Journal of Marketing Management, 30(1-2), 172-200.

[2] Baswedan, A. R. (2004). Political Islam in Indonesia: present and future trajectory. Asian Survey, 44(5), 669-690.

[3] Berger, A. (2010). The objects of affection: semiotics and consumer culture. Springer.

[4] Berger, A. A. (1997). Narratives in Popular Culture, Media, and Everyday Life. London and New York: Sage.

[5] Berger, P. L., \& Luckmann, T. (1991). The Social Construction of Reality: A Treatise in The Sociology of Knowledge. London: Penguin UK.

[6] Bianchi, C. (2011). Semiotic approaches to advertising texts and strategies: Narrative, passion, marketing. Semiotica, 2011(183), 243-271.

[7] Briandana, R., \& Dwityas, N. A. (2018). Comedy Films as Social Representation in the Society: An Analysis of Indonesian Comedy Films. International Journal of Humanities and Social Science Studies (IJHSSS), 6959(107), 107-118.

[8] Bungin, B. (2008). Konstruksi Sosial Media Massa: Kekuatan Pengaruh Media Massa, Iklan Televisi dan
Keputusan Konsumen serta Kritik Terhadap Peter L. Berger \& Thomas Luckmann.

[9] Creswell, J. W., \& Miller, G. A. (1997). Research methodologies and the doctoral process. New Directions for Higher Education, 1997(99), 33-46.

[10] Eco, U. (1986). Semiotics and the Philosophy of Language (Vol. 398). Indiana University Press.

[11] Elliott, R., \& Wattanasuwan, K. (1998). Brands as Symbolic Resources for the Construction of Identity. International Journal of Advertising, 17(2), 131144.

[12] Fiske, J. (2012). Pengantar ilmu komunikasi. Jakarta: Rajawali Press.

[13] Freire, N. A. (2014). When luxury advertising adds the identitary values of luxury: A semiotic analysis. Journal of Business Research, 67(12), 2666-2675.

[14] Gazali, E., Hidayat, D. N., \& Menayang, V. (2009). Political communication in Indonesia: media performance in three eras. In Political communication in Asia (pp. 120-142). Routledge.

[15] Harvey, M., \& Evans, M. (2001). Decoding competitive propositions: a semiotic alternative to traditional advertising research. International Journal of Market Research, 43(2), 171.

[16] Holland, K., Warwick Blood, R., \& Thomas, S. (2015). Viewing The Biggest Loser: Modes of Reception and Reflexivity Among Obese people. Social Semiotics, 25(1), 16-32.

[17] Holtz-Bacha, C., \& Kaid, L. L. (2014). Political advertising in international comparison. The Handbook of International Advertising Research, 554-574.

[18] Honna, J. (2013). Military politics and democratization in Indonesia. Routledge.

[19] Jankowski, N. W., \& Jensen, K. B. (2002). A handbook of qualitative methodologies for mass communication research. London: Routledge.

[20] Johnson Tan, P. (2012). Reining in the reign of the parties: Political parties in contemporary Indonesia. Asian Journal of Political Science, 20(2), 154-179.

[21] Kaid, L. L., \& Holtz-Bacha, C. (2006). The Sage handbook ofpolitical advertising. Sage Publications.

[22] Kotler, P., Kartajaya, H., \& Setiawan, I. (2016). Marketing 4.0: Moving from traditional to digital. John Wiley \& Sons.

[23] Mcilwain, C. D. (2007). Race, pigskin, and politics: A semiotic analysis of racial images in political advertising. Semiotica, 2007(167), 169-191.

[24] Mcmillin, D. C. (2016). Choosing Commercial Television's Identities in India: A Reception Analysis. Continuum, 4312(March). https://doi.org/10.1080/10304310220121037 
[25] Mietzner, M. (2013). Money, power, and ideology: Political parties in post-authoritarian Indonesia. NUS Press.

[26] Morissan, M. (2016). The Influence of Politicians on Television Content in Post-Authoritarian Indonesia. JSP (Jurnal Ilmu Sosial Dan Ilmu Politik), 20(3), 204-220.

[27] Morley, D. (2003). Television, audiences and cultural studies. London and New York: Routledge.

[28] Najafian, M., \& Ketabi, S. (2011a). Advertising social semiotic representation: a critical approach. International Journal of Industrial Marketing, l(1), 63.

[29] Najafian, M., \& Ketabi, S. (2011b). The words behind images: A critical social semiotic approach toward analyzing advertising. International Journal of Linguistics, 3(1), 47.

[30] Richards, J. I., \& Caywood, C. L. (2014). Symbolic speech in political advertising: encroaching legal barriers. Television and Political Advertising, 2, 231-256.

[31] Sen, K., \& Hill, D. T. (2006). Media, culture and politics in Indonesia. Equinox Publishing.

[32] Sendjaja, S. D., Rahardjo, T., Pradekso, T., \& Sunarwinadi, I. R. (2014). Teori Komunikasi. Jakarta: Universitas Terbuka.

[33] Sobur, A. (2001). Analisis teks media: suatu pengantar untuk analisis wacana, analisis semiotik dan analisis framing. Remaja Rosdakarya.

[34] Solík, M. (2014). Semiotic approach to analysis of advertising. European Journal of Science and Theology, 10(1), 207-217.

[35] Tanuwidjaja, S. (2010). Political Islam and islamic parties in Indonesia: critically assessing the evidence of Islam's political decline. Contemporary Southeast Asia: A Journal of International and Strategic Affairs, 32(1), 29-49.

[36] Ufen, A. (2008). Political party and party system institutionalization in Southeast Asia: lessons for democratic consolidation in Indonesia, the Philippines and Thailand. Pacific Review, 21(3), 327-350. 